\begin{tabular}{|l|l|l||}
\hline \multicolumn{2}{|c|}{ PublisherInfo } \\
\hline \hline PublisherName & $:$ & BioMed Central \\
\hline \hline PublisherLocation & $:$ & London \\
\hline \hline PublisherImprintName & $:$ & BioMed Central \\
\hline \hline
\end{tabular}

\title{
Genetic alterations in breast stroma may influence epithelial neoplasia
}

\begin{tabular}{|l|l|l||}
\hline \multicolumn{2}{|c||}{ ArticleInfo } \\
\hline \hline ArticleID & $:$ & 3718 \\
\hline \hline ArticleDOI & $:$ & $10.1186 /$ bcr-2000-66681 \\
\hline \hline ArticleCitationID & $:$ & 66681 \\
\hline \hline ArticleSequenceNumber & $:$ & 84 \\
\hline \hline ArticleCategory & $:$ & Paper Report \\
\hline ArticleFirstPage & $:$ & 1 \\
\hline \hline ArticleLastPage & $:$ & 3 \\
\hline \hline & $:$ & RegistrationDate : 2000-6-2 \\
ArticleHistory & $:$ & OnlineDate \\
\hline \hline ArticleCopyright & $:$ & Current Science Ltd2000-6-2 \\
\hline \hline ArticleGrants & $:$ & \\
\hline \hline ArticleContext & $:$ & 1305822 \\
\hline \hline
\end{tabular}


Jenny Gomm, ${ }^{\text {Affl }}$

Affl University of Sussex, Brighton

\section{Keywords}

Loss of heterozygosity (LOH), mammary, microdissection, neoplasia, stroma

\section{Introduction}

Genetic alterations such as loss of heterozygosity $(\mathrm{LOH})$ have been observed in many benign and malignant epithelial neoplasms; however, their cellular source has not always been identified.

\section{Aims}

To examine the possibility and frequency of LOH in the mammary stroma from women with and without breast cancer.

\section{Comments}

The results in this study support the concept of reciprocal stromal-epithelial interactions in mammary tumorigenesis. However, the sample numbers are very small and would therefore need to be expanded. The difficulties of the technique meant that informative cases for a specific DNA loci could be as low as two or three patients and in a former study the authors found only $3 / 25$ stromal samples exhibited any genetic abnormality. Nevertheless it is food for thought.

\section{Methods}

Using polymorphic DNA markers on chromosomes 2p, 3p, 11q, 16g and 17q which are known for their high frequency of LOH in breast cancer, PCR was carried out on microdissected samples of either 
the epithelial component or stromal tissue close to or further away from $(15 \mathrm{~mm})$ areas of ductal carcinoma in situ (DCIS) or intraductal carcinoma (IDC) from 11 patients. Epithelial cells from morphologically normal ducts within cancer tissue and ten samples of reduction mammoplasty (RM) were used as controls.

\section{Results}

LOH (complete absence or $75 \%$ reduction in one allele assessed by direct visualisation) was found to be a frequent occurrence in both the epithelial and stromal components of cancer tissue from women with DCIS and IDC. Out of 12 DNA loci, 11 showed LOH in the stroma close to the cancer cells and 10 out of 12 in the morphologically normal stroma at least $15 \mathrm{~mm}$ away. The $\mathrm{LOH}$ frequency ranged from $10-80 \%$ of patient samples for the former and $11-57 \%$ for the latter. Importantly, several microsatellite loci were lost only in the stromal cells in five patients. Four DNA markers showed LOH in epithelium that had a normal appearance from cancer tissues from $16-40 \%$ of women. None of the $10 \mathrm{RM}$ samples exhibited LOH in either epithelial or stromal fractions.

\section{Discussion}

The most common loci identified with LOH in the stromal cells in this study contain, or are close to, several putative tumour suppressor genes including BRCA1, E-cadherin, FHIT and ataxia telangiectasia, which are commonly lost in breast cancer. This could lead to abnormal production of growth factors responsible for the maintenance of normal epithelial cells and extracellular matrix. Also, since $\mathrm{LOH}$ in certain DNA loci was found exclusively in the stroma this would suggest that these genetic alterations precede those taking place in the epithelial cells and may even induce neoplastic change in these cells.

\section{References}

1. Moinfar F, Man YG, Arnould L, Bratthauer GL, Ratschek M, Tavassoli FA: Concurrent and independent genetic alterations in the stromal and epithelial cells of mammary carcinoma: implications for tumorigenesis. Cancer Res. 2000, 60: 2562-2566.

This PDF file was created after publication. 